\title{
The Blundered Strategy of Euro Adoption in the Czech Republic: A "Pre-crisis" Retrospective
}

\section{Vladislav Flek ${ }^{1}$}

\begin{abstract}
The commitment to join the eurozone in 2009-2010 was rejected by Czech Republic in 2006 at a time when signs of the eurozone crisis were not yet apparent. Nor did the prospects of failure to fulfil any of the Maastricht Convergence Criteria have any realistic basis. Real or alleged difficulties in meeting the Maastricht Convergence Criteria and attaining economic alignment with the eurozone did not serve as a mobilization factor for economic policies. Instead, these issues were perceived to offer an objective reason against euro adoption within the declared timeframe. The official stance against the euro was partly based on serious analytical and short-term forecasting errors, if not on deliberate manipulations, including an overemphasised misalignment of the Czech economy with the eurozone.
\end{abstract}

Keywords: Czech Republic, eurozone, Maastricht Convergence Criteria, nominal and real convergence, single European currency.

JEL Classification: F33, E42

\section{Introduction}

It is generally acknowledged that the Czech Republic's membership in the eurozone has never been a topical issue for any Czech government. In the light of the current economic, fiscal and financial crisis in some eurozone countries, and especially in view of the situation in countries in the literature referred to as PIIGS (Portugal, Italy, Ireland, Greece, and Spain), such attitude looks natural, almost wise.

The greatest problems faced by these countries are in the area of excessive public sector deficits, total indebtedness, contractions in the banking sector, economic recession, increasing unemployment and related social tensions. In order to cope with these problems the eurozone will probably have to reshape its current institutional design and engage an unprecedented amount of financial means. The future functioning of the eurozone, the number of its members and the precise rules of the game are difficult to predict for potential new eurozone entrants.

Yet, it is of legitimate research interest to answer a question about what had actually prevented the Czech Republic from seeking to join the eurozone in the good, pre-crisis times together with Slovenia, Malta, Cyprus and Slovakia. Where are the roots of the Czech reluctance? Was it the country's ability to spot the signs of the eurozone crisis

\footnotetext{
${ }^{1}$ Metropolitan University Prague, Department of International Trade, Czech Republic, email: flek@ mup.cz. The author wishes to thank Zdeněk Čech and Lubor Lacina for valuable comments and suggestions. However, the views expressed in the present article remain solely those of the author.
} 
earlier than others? Were there serious internal economic obstacles to adopt the euro? Or was it mainly due to the lack of political commitment, with economic arguments playing just a subordinate role?

In order to answer these questions, we shall concentrate on a situation before the crisis significantly changed political and economic environment in Europe, especially on the period between the entry of the Czech Republic to the European Union in May 2004 and the year 2008. We believe that the lessons learned from the pre-crisis period are in many respects relevant for future decisions related to adoption of the euro in the Czech Republic.

In the following sections we demonstrate a lack of strong economic arguments to justify the negative government stance towards adopting the single European currency in the above-noted period. Furthermore, we show that the existing key arguments were partly based on serious analytical and short-term forecasting errors, if not on deliberate manipulations. Contrary to popular beliefs, we also challenge the view that Czech National Bank was the key or sole actor responsible for the country's negative attitude towards the adoption of the euro.

\section{Government Decision-Making: A Summary}

This section opens with a brief discussion of economic conditions to be met by any EU member state with temporary derogation to enter the eurozone. ${ }^{2}$ This conceptualization is then confronted with the development of the actual decision-making processes tied to the preparation of the Czech Republic's (hereafter referred to as the CR) accession into the eurozone.

During the years 2004-2008, two interrelated factors were crucial for the country's entry into the eurozone: (i) the readiness of the national economy in terms of the required degree of sustainable economic convergence, ${ }^{3}$ and (ii) broader economic considerations which include adequate structural and cyclical alignment of the national economy with the eurozone. ${ }^{4}$ Just from 2008 onwards we have to add another factor: the dynamics of eurozone crisis.

The interdependence of the first two factors is evident and has both intuitive and theoretical support. ${ }^{5}$ It tells us that even an economy fulfilling the Maastricht Convergence Criteria in spite of its inflexible markets, pronounced lags in productivity or price levels and its unaligned economic cycle with the eurozone, might lose rather than gain from joining the monetary union, especially in the short run.

\footnotetext{
${ }^{2}$ Authoritative interpretation of legal and economic aspects of this procedure by European Commission and European Central Bank is summarised by e.g. Stark (2008).

${ }^{3}$ This factor is embodied in the Maastricht Convergence Criteria. See European Commission (2008), ECB (2008) or Assessments (2004-2008) for detailed evaluation with regard to the CR.

${ }^{4}$ The second factor focuses primarily on seeing the Maastricht Convergence Criteria met in a manner supported by adequate flexibility of particular markets, comparable price and productivity levels, and the national business cycle aligned with the eurozone. Analyses (2008) provide extensive evaluation for the CR.

${ }^{5}$ This support comes from the theory of optimum currency areas (Mundell, 1961). For discussion which relates to the CR also see Dědek (2002), Komárek et al. (2003), Flek et al. (2004), Lacina, Rozmahel et al. (2010).
} 
Any responsible government would then incline towards a rather cautious approach towards declaring the euro changeover date. With such approach, a country is allowed to apply an independent national monetary policy and can make use of the equilibrating role of exchange rate adjustments for an extended period. The impact of the convergence process may thus diffuse efficiently through both the domestic price- and the nominal exchange rate channels. As a result, the country would avoid the costs of a premature entry into the eurozone, such as accelerating domestic inflation, potentially inappropriate ECB monetary policy stance and lower ability to absorb future asymmetric shocks to name but the most important ones.

In contrast, when both factors show positive results, one may hope that the benefits of introducing the euro will be maximised and may judge the national economy to be ready to enter the eurozone. Such a diagnosis should result in a political decision in favour of a swift introduction of the euro. Otherwise, postponing the entry into the eurozone can needlessly raise the costs of preserving national currency, such as currency risk, transaction costs linked with currency conversions, barriers to deeper integration between domestic business and the eurozone, less inflow of foreign investment and lower price transparency.

The specific Czech approach to the introduction of the euro has been laid down in official documents from the very beginning. The first of the official documents issued by the government and the central bank is "The Czech Republic's Euro-area Accession Strategy", approved on October 13, 2003, i.e. practically on the eve of the country's accession to the European Union.

The document formulates the benefits and risks connected with the entry into the eurozone as well as the related demands on domestic economic policy and desired functioning of particular markets. It stipulates that "the government's strategic aim is to introduce conditions for adoption of the euro in the CR". Finally, it formulates a target date for euro adoption as follows: "Presuming successful fulfilment of the Maastricht Convergence Criteria, including successful consolidation of public finances, the achievement of an adequate level of real convergence and reasonable progress with regard to structural reforms guaranteeing sufficient economic alignment with the countries of the EU, accession of the CR to the eurozone may be anticipated in 20092010" (Strategy, 2003, p. 8).

As part of their Strategy the government and the central bank committed to annually carry out an evaluation of the CR's readiness for entry into the eurozone. Readiness was defined both in terms of current and anticipated fulfilment of the Maastricht Convergence Criteria as well as of the economic alignment of CR with the eurozone. This annual assessment was to result in recommendations as to whether in the following year the procedure should be initiated for the national currency to enter the ERM II mechanism for a minimum of two-year period, and consequently to enter the eurozone.

As documented above, the way in which the Strategy declared the period of 2009-2010 as euro changeover target date was very conditional. That is why it remained unclear even to Czech central bankers how seriously this declaration was intended. ${ }^{6}$ No wonder

${ }^{6}$ Closed Bank Board session held on June 30, 2005 evidences that Czech central bankers were indeed uncertain with respect to government intentions to adopt the euro. That is why vice- 
that in such circumstances the country was lagging behind in terms of institutional and logistical support required for transition to the single European currency. ${ }^{7}$ In reality, the process never achieved a level comparable to that in countries seriously seeking to adopt the euro (see Lalinsky, 2010, for comparison with Slovakia).

The 2004 Assessment was approved by the government on 12 January 2005. The recommendation to the government called for the CR not to apply for entry into the ERM II mechanism, stating that "conditions have not been created for the time being which would allow the CR to fulfil the designated conditions for entry into the eurozone two years after entry into ERM II. The country would thus not benefit from adopting the euro". In addition to a failure to fulfil the government's general deficit criterion and facing unresolved long-term fiscal problems, the document notes "structural problems" of the Czech economy. Both sets of arguments, with certain variations, serve as the basis for all other documents officially formulating the position of the $\mathrm{CR}$ on introduction of the euro (see also Helísek et al., 2009).

Another major milestone in timing entry into the eurozone came in 2006 with a definitive hold placed on all attempts to introduce the single European currency before 2010. The October 2006 Assessment again adopted the negative view of not recommending that the CR enters the ERM II mechanism in 2007. This led to a proposed" shift in the potential entry date of the CR into the eurozone beyond the 20092010 timeframe originally envisaged" (Assessment, 2006, p. 6).

Further significant episode came with the approval of "The Czech Republic's Updated Euro-area Accession Strategy“ in August 2007. Arguments presented in this document led to the definitive rejection of any new euro changeover target date: "The date for adoption of the euro... depends upon resolving... problem areas as part of a fundamental reform of public finance and reinforcing the flexibility of the Czech economy“ (Updated Strategy, 2007, p. 9).

In the next section we concentrate mainly on the arguments related to Maastricht Convergence Criteria and analyse their relevance for government decision-making processes.

governor Niedermayer proposed “... to ask the politicians whether we really should rely on the year 2009. Otherwise there is a threat of delaying the timely entry into to ERM II, and the declared euro changeover target date would be impossible to fulfil." Governor Tůma added that it is hard for Czech National Bank “... to undertake strong steps towards euro changeover preparations in a situation when the current political position (or the one in 2006) towards this issue is unknown" (Protocol, 2005, p. 6).

${ }^{7}$ A timetable including organizational measures to introduce the euro in CR on 1 January 2009 is contained in a Ministry of Finance document titled "Institutional Support for the Adoption of the Euro in the Czech Republic", approved by the government in November 2005. It involves timetables for introduction of the euro and calls for entry to ERM II during the first half of 2006. National coordinator was named and National Coordination Group for Euro Adoption was set up. But the document was never implemented in full, mainly due to the discontinuity stemming from the parliamentary elections of June 2006. National Euro Changeover Plan was finally approved by the new government in April 2007; however, it includes no euro changeover target date. 


\section{Why Did We Actually Give Up?}

International comparisons demonstrate that during its entry into the EU in 2004, the CR could have been compared to Slovenia, Slovakia, Cyprus, and Malta as regards its ability to meet the Maastricht Convergence Criteria (Table 1).

Table 1: Fulfilment of the Maastricht Convergence Criteria (2004)

\begin{tabular}{|l|c|c|c|c|}
\hline & price stability & $\begin{array}{c}\text { government budgetary } \\
\text { position } \\
\text { (deficit, debt) }\end{array}$ & exchange rates & $\begin{array}{c}\text { long-term } \\
\text { interest rates }\end{array}$ \\
\hline Czech R.* $^{*}$ & Yes & No & x & Yes \\
\hline Slovakia* & No & No & x & Yes \\
\hline Slovenia & No & Yes & x & Yes \\
\hline Cyprus* & Yes & No & x & Yes \\
\hline Malta* & No & No & x & Yes \\
\hline
\end{tabular}

Note: * Excessive deficit procedure launched against country by Council decision of July 5 , 2004. X - the criterion cannot be evaluated due to the absence in the ERM II mechanism.

Source: Assessment (2004, p. 4).

Yet, while all these countries managed to introduce the euro during the 2007-2009 period, the CR backed off in October 2006. Note that upon entry to the EU, the CR was one of the few countries listed in Table 1 to fulfil the inflation criterion. Together with the other countries, it also fulfilled the criterion on long-term interest rates and fulfilled the government debt criterion. No country (with the exception of Slovenia) fulfilled the criterion on general government deficit of -3\% of GDP. That is why, soon after entering the EU, the Council decided on July 5, 2004, to invoke the excessive deficit procedure (EDP) against the countries in question.

This procedure intended to ensure that the deficit would be reduced in a "sustainable and credible way" to under the -3\% GDP threshold by 2008. For the CR, the EU agreed to a plan of gradual deficit reduction proposed by the Czech government as a part of the Convergence Program of May 2004, based upon the fiscal goals of governmental reform of public finance from 2003. Table 2 indicates progress in meeting the government deficit criterion in all affected countries in successive years.

Table 2: General government deficits (in \% of GDP)

\begin{tabular}{|l|c|c|c|c|}
\hline & 2005 & 2006 & 2007 & 2008 \\
\hline EU 27 & -2.4 & -1.4 & -0.8 & -2.3 \\
\hline eurozone & -2.5 & -1.2 & -0.6 & -1.9 \\
\hline Czech Rep. & -3.6 & -2.6 & -0.6 & -1.5 \\
\hline Slovakia & -2.8 & -3.5 & -1.9 & -2.2 \\
\hline Slovenia & -1.4 & -1.3 & 0.5 & -0.9 \\
\hline Cyprus & -2.4 & -1.2 & 3.4 & 0.9 \\
\hline Malta & -2.9 & -2.6 & -2.2 & -4.7 \\
\hline
\end{tabular}

Source: Fiscal Outlook of the Czech Republic (2009, p. 50). 
Objectively, it must be noted that this was largely a temporary state of affairs and was to a high degree due to an unexpectedly positive GDP growth in the given phase of the business cycle. As a result, fulfilling the criteria on public finance sustainability did not necessarily mean a truly deep, long-term fiscal consolidation. Indeed, financial and economic crisis showed soon a dramatic impact on fiscal position of the majority of EU member states. Out of the 27 EU member states 26 were on the list of countries with excessive deficits in 2010 (European Commission, 2010).

However, seeing from the time perspective of 2005-2008, all countries gradually began to meet the criteria on government deficit and also had a favourable outlook for obeying the EU's medium-term fiscal rules. Therefore, the EDP procedure was abrogated in all the aforementioned countries in June 2008, including the CR. Consequently, the results in Table 2 suggest that neither the temporary failure to fulfil the government deficit criterion, nor the invocation of the EDP procedure constituted a real obstacle for any of the countries to access the eurozone within the planned timeframe.

Prospects of the CR to enter the eurozone as of January 1, 2009, may hypothetically be judged on the basis of Convergence Reports executed by European Commission and European Central Bank in 2008. As of that date, the CR had failed to fulfil only the inflation criterion (see Table 3). Using the 12-month average of the harmonized consumer price index of 3.2\% as a reference value (April 2007-March 2008), inflation in $\mathrm{CR}$ in the same period was $4.4 \%$, i.e. 1.2 percentage points above the reference value.

During the reference period, inflation reflected the global energy and food price shocks, and also substantial rise in indirect taxes and administered prices in the CR. However, the second factor alone appears to be responsible for the country's failure to fulfil the price stability criterion in March 2008. ${ }^{8}$ Although inevitable in principle, price deregulation and tax harmonisation measures with strong inflationary impact clearly had to be avoided in the year preceding the targeted euro changeover date providing the target date was meant seriously. ${ }^{9}$

Simulations made by the Czech National Bank show that meeting the exchange rate stability criterion would have been feasible in the period 2006-2007 (Assessment, 2008, p. 13). That is why one may argue that, with a different timing of tax harmonisation and price deregulation (or with slightly more restrictive monetary policy stance), the CR

\footnotetext{
${ }^{8}$ Indeed, at the beginning of 2008 the inflationary impact of price deregulation and tax harmonisation measures was relatively strong: “...the first-round effects of indirect tax changes including a preferential VAT rate increase (from 5\% to 9\%), introduction of an environmental tax and a hike in tobacco excise duties - are estimated to have contributed by around 2 percentage points to the increase in annual headline inflation in January 2008. Increases in regulated prices, in particular to the housing and energy, have also added significantly to price dynamics. Newly introduced health-care regulatory fees accounted for about $1 / 2$ percentage points of annual price growth in January 2008" (European Commission, 2008, p. 67).

${ }^{9} \mathrm{CNB}$ was aware of the risk of nonfulfillment of the price stability criterion resulting from the planned price deregulation and tax harmonisation: "The likelihood of non-fulfillment of the criterion depends on ...the strength of the impact of the planned changes to indirect taxes: the Ministry of Finance outlook indicates that there should be no problem, whereas the CNB outlook regards future non-fulfillment of the criterion as highly likely if the current inflation target of $3 \%$ is maintained" (Assessment 2006, p. 4).
} 
would have fulfilled all the Maastricht Convergence Criteria in March 2008 and would have been allowed to access the eurozone in 2009 together with Slovakia (see Table $3) .^{10}$

Table 3: Fulfilment of Maastricht Convergence Criteria (April 2007-March 2008)

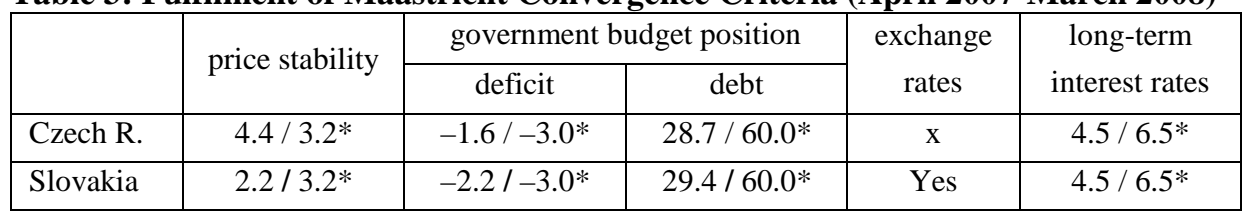

Notes: * reference value of the criterion (in per cent) to allow the country to enter the eurozone on 1 January 2009; $x$ - the criterion cannot be evaluated because of the absence of the CR in the ERM II mechanism.

Source: ECB (2008).

In the following section we place our chief focus on fiscal developments in the CR, as the alleged failure to fulfil the government deficit criterion was the major official argument to reject the originally set euro changeover date.

\section{Government Deficit: A Closer Look}

The following was the key official argument against the euro adoption raised in 2006: "Current public finance parameters do not allow the deficit criterion to be met... The proposed state budget for 2007 confirms a worsening trend in the development of public finance which will not permit the CR to maintain the consolidation strategy to which it obligated itself upon entry into the EU" (Assessment, 2006, p. 9).

As evidenced by Table 2, this presumption has not been confirmed. Even the not quite ambitious approach to public finance reform from 2006 was enough to ensure the fulfilment of the government deficit criterion for the year. Obviously, unexpectedly high economic growth also played a role, along with the fact that the Ministries transferred their unspent funds from overestimated budgets into reserve funds.

The October 2006 Assessment expressed concerns that social expenditures which had been dramatically increased in the pre-election atmosphere of 2006, would not permit to terminate the EDP procedure within the designated deadline (i.e. in 2008). This would create a legal impediment to the entry into the eurozone in line with the originally envisaged timeframe of 2009-2010. However, when 2007 came around, the government deficit displayed comfortable fulfilment of the criterion on fiscal sustainability (Table 3). Nonetheless, the Assessment from December 2007 still misleadingly continues to signal a failure to fulfil this criterion for 2007 (with the deficit estimated at $-3.4 \%$ of GDP).

\footnotetext{
${ }^{10}$ This is not to say that in 2008 , European authorities did not formulate a wide range of partial objections with regard to long-term sustainability of fulfilment of Maastricht Convergence Criteria both in the CR and Slovakia. The same applies to the achieved degree of economic alignment of both countries with the eurozone. But, as evidenced by the case of Slovakia, these reservations did not represent crucial obstacle to the country accession to the eurozone in 2009.
} 
In relation to this, let us not forget that just three months later, the Commission proposed to abrogate the EDP procedure as regards the CR. ${ }^{11}$ In subsequent two months (i.e. in May, 2008), the Convergence Reports of European Commission and ECB stated that the Czech government deficit for 2007 was $-1.6 \%$ of GDP, i.e. far below the $-3 \%$ reference value. ${ }^{12}$ The public finance sustainability criterion required for introduction of the euro by 2009 was in fact easily met by the CR and the key government argument of "legal obstacles" for entry of the CR into the eurozone before 2010 was therefore odd. ${ }^{13}$

Can all this be explained just by an honest fiscal forecasting error? We have serious reasons to believe that there was much more behind such seemingly poor forecasting performance of Czech fiscal authority. Indeed, it is evident that its "...practice of making overly conservative estimates of current-year fiscal outcomes, which introduces an additional source of uncertainty, should be reconsidered“" (ECB 2008, p. 74).

\section{Economic Alignment with the Eurozone}

In addition to the alleged incapability to meet the government deficit criterion, voices from Czech National Bank pointed out a low economic alignment of the Czech economy with the eurozone (i.e. to the second factor of our categorisation made in Section 1). The rest of this section examines this official argument. ${ }^{14}$

Two groups of factors are central to determining the degree of economic alignment with the eurozone: (i) the similarity of cyclical and structural characteristics; and (ii) the functioning of adjustment mechanisms. The first group of factors includes a degree of real convergence achieved by a candidate country, similarity in the economy's structural profile and business cycle evolution, integration of particular markets etc. Flexibility of labour and product markets, and the ability of fiscal policy to stabilise the economy are the most important factors which form the second group.

The key document each year evaluating the factors for the CR noted above is called "Analyses of the Czech Republic's Current Economic Alignment with the Euro Area“. It represents a collection of analyses made by Czech National Bank with a strong influence on all government's Assessments discussed in the previous section. Analyses from 2008 are most relevant for our purposes since they evaluate the situation one year before the original target date of the CR's accession into the eurozone.

\footnotetext{
${ }^{11}$ A press release of the Ministry of Finance from May of 2008 says: "According to the notification data, the public sector deficit should remain lower than the reference value in the Maastricht Convergence Criteria for three years in a row (2006-2008). The matter of terminating the EDP procedure has arisen as a result. At the end of March 2008, the Ministry of Finance received a proposal from the European Commission to terminate the EDP in advance (under standard operating procedures, CR was evaluated only after spring notifications in 2009). The Ministry of Finance welcomes this initiative on the part of the Commission."

${ }^{12}$ This figure was even more favourable after further notifications (i.e. $-0.6 \%$, see Table 2).

13 There was obviously more to having the EDP terminated in June 2008 than just the satisfactorily low government deficit relative to GDP for 2007. At that time, it also entailed medium-term consolidation measures designed to meeting the structural deficit target of $-1 \%$ of GDP by 2012, i.e. fully in line with obligations of the CR with respect to the EU fiscal rules.

${ }^{14}$ See also Flek (2010) for discussion.
} 
First, we concentrate on the most important factor of economic alignment, i.e. on the degree of real economic convergence achieved. The Analyses acknowledge undisputable progress in real convergence in terms of real GDP per capita: "This process has accelerated in the last five years or so. With this indicator currently at almost $75 \%$ of the euro area average, the Czech Republic ranks between Portugal and Slovenia, i.e. it has a standard of living comparable with the least advanced countries of the monetary union“" (Analyses, 2008, p. 17). ${ }^{15}$

The Analyses also state that the level of real GDP per capita in the CR was by some ten percentage points closer to the eurozone average than Slovakia. However, despite having provided these relatively favourable data, the Analyses fail to conclude from this perspective on the readiness of the CR to join the eurozone.

Comparability of domestic price level with that in the eurozone is another related problem. The Analyses note that the price level in the CR was below the one that would correspond to the economic level achieved (in 2007, price level in CR corresponded to just $60 \%$ of the eurozone average). However, for 2008 the document expected that the domestic price level would approximate the European average by some ten percentage points, above all due to a strong nominal exchange rate appreciation trend. Considering the already achieved $75 \%$ of the EU level of GDP per capita, most of the existing gap between the domestic price- and economic levels would have been dissolved.

The 2008 Analyses worried about the possible real exchange rate appreciation pressures related to further catching-up in productivity with the eurozone (the so-called BalassaSamuelson effect). These pressures were estimated between $1.3 \%$ and $2.4 \%$ per year. If we take these figures for a fact, with abandoning the national currency in 2009 this real appreciation trend would have transformed itself fully into the domestic price channel. In other words, inflation differential between the CR and the eurozone based on the real convergence process would have ranged somewhere between 1 and 2 per cent.

The document claims that if such not particularly strong inflation differential persists after joining the EMU, it could have an adverse effect on macroeconomic and financial stability in the CR. Such a strong statement would obviously require more justification. Moreover, it neglects available alternative estimations delivering evidence that further catching up in productivity cannot create any significant long-term inflationary trend in the CR. A newer strand of literature is equally sceptical with respect to the relevance of the Balassa-Samuelson effect for the CR and other new EU member countries. ${ }^{16}$

\footnotetext{
${ }^{15}$ What was even more favourable than the above-noted convergence in terms of real GDP per capita was the structure of economic growth in the CR. As shown by Dybczak et al. (2006), annual potential output grew during 2002-2005 on average by $4.2 \%$, as compared with just $2.7 \%$ recorded for 1995-2005. The results for 2006 and 2007 were even more favourable, see Hájek (2008). These figures therefore show that acceleration in the real convergence process was accompanied by potential output growth. Even more importantly, the decisive part of potential output growth was due to increases in total factor productivity. This means that the real convergence process in the CR was not only quite rapid in absolute terms, but also firmly based on positive fundamental characteristics of the Czech economy.

${ }^{16}$ Flek et al. (2003) show that the Balassa-Samuelson effect for the CR is (and will remain) very close to zero. This finding is supported by Egert (2002) and Mihajlek, Klau (2003). See also Lein et al. (2008). Considering non-trivial problems with the estimation procedure, Mihajlek, Klau
} 
Also the analysis of other indicators of economic alignment does not deliver convincing arguments against the entry of CR into the eurozone. Above all, this concerns the cyclical alignment with the eurozone. In this sense, the Analyses argue that “... compared to the countries under review, the cyclical alignment of the Czech Republic is roughly average and the measured correlation is, for example, somewhat higher than that for the currently acceding Slovakia" (Analyses, 2008, p. 21).

What was the CNB telling us about the state of the adjustment mechanisms? In general, labour market flexibility and the ability of national fiscal policy to respond to macroeconomic shocks will gain in importance after adoption of the euro. The reason is simple: after abandoning the national monetary policy and closing the exchange rate equilibrating channel, the above-noted adjustment mechanisms will remain the key factor for restoring macroeconomic stability at the national level.

In sharp contrast to previous years, the 2008 Analyses eventually acknowledged improvement in public finances in the CR and expressed an outlook of meeting the public deficit criterion and preserving a relatively favourable level of public debt. Some concerns are expressed with regard to a high share of mandatory expenditures in public expenditures and long-term problems linked especially with population ageing. Both aspects are claimed to reduce the room for fiscal policy manoeuvres in case of future macroeconomic shocks. However, instead of fiscal issues, the document concentrates on the situation on the labour market, which is subject to severe criticism.

The Analyses claim that insufficient real wage flexibility prevails on domestic labour market. Furthermore, sharp differences in regional unemployment rates, high redundancy costs and high long-term unemployment are likely to undermine the equilibrating role of the Czech labour market. On the other hand, the Analyses notice partial improvement in structural unemployment while stressing the positive impact of inflow of foreign labour force on labour market competition.

Such partial analyses, however, cannot deliver the synthetic view on labour market development, and on whether it represents an obstacle to adopt the euro. The Analyses fail to evaluate relative contributions of "positive" and "negative" observations to the overall shape of the labour market. Any well-defined benchmark to judge the overall Czech labour market performance is absent in the Analyses.

The document lacks answers to key questions: What degree of real wage flexibility is "high enough" for the CR to enter the eurozone? Is improvement in structural unemployment less relevant than the persistence of regional disparities in unemployment rates? As a result, an uninformed reader may conclude that any of the still existing labour market imperfections actually represent an obstacle to joining the eurozone. The Analyses also appear to underestimate/ignore some of the key labour

(2008, p. 17) warn that "we should perhaps caution against attempts to start using estimates of the Balassa-Samuelson effects in policy assessment". The contemporary view is as follows: "Despite its strong theoretical position when it comes to explaining inflation in transition economies, the empirical findings of the Balassa-Samuelson (B-S) effect assign only a minor role to structural inflation - to the disappointment of analysts and policymakers" (Borgersen, King, 2011, p. 287). 
market trends in the $\mathrm{CR}$, namely a positive contribution of labour to potential output growth since 2004 as well as a break in an increasing trend in the NAIRU since $2000 .{ }^{17}$

Because of the conceptual limitations noted above, the Analyses fail to provide convincing arguments that the CR could not adopt the euro in 2009 because of insufficient labour market performance. At the same time, in the analysed period, the CR achieved undisputable progress in nominal and real convergence, cyclical synchronisation with the eurozone and in most of the remaining relevant characteristics of economic alignment. In any case, none of the still prevailing shortcomings in economic alignment appear to be strong enough to justify the government decision not to join the eurozone within the originally set timeframe.

\section{Concluding remarks}

In this article we attempted to address the issue of why the CR decided not to introduce the euro when the window of opportunity was still open before the crisis. There were two major official economic reasons: (i) uncertainty concerning fiscal development, namely distrust as to whether the country could free itself from the excessive deficit procedure in time; and (ii) great emphasis on allegedly inadequate flexibility of domestic markets and an insufficient alignment of the Czech economy with the eurozone.

The first reason proved to be invalid, as it was based on serious short-term forecasting error, if not on deliberate manipulation with short-term fiscal outlook. From this perspective, the tale of how the target date for introduction of the euro in the CR came to be put off allows for some generalisations. Namely, it may serve as a textbook example of how risks and uncertainties inherent in the economic forecasting process affect irreversibly key political decisions.

The second officially articulated reason remains highly disputable and open to fundamental criticism. The problems linked to structural problems of the Czech economy and the economic alignment with the eurozone were overemphasised in order to provide additional justification for the CR not to enter the ERM II and not to join the eurozone. Note that the further we move away from the Maastricht Convergence Criteria and the more we focus on economic alignment, the more the difficulty arises of selecting appropriate indicators for assessing "sufficient" progress for the introduction of the euro. Such a selection would always be somewhat arbitrary.

One can even imagine that there is always a space for improvement before the euro is adopted. We may never be certain that the Maastricht Convergence Criteria will be fulfilled in a sustainable manner and the economy may never be "adequately" aligned. Entering the eurozone thus becomes "permanently" impossible. We suspect that this is

\footnotetext{
${ }^{17}$ See Flek (2007) or Dybczak et al. (2006) for more detail. Note also that the CR reached in 2004 the fifth lowest Employment Protection Index among the OECD countries. In 2007 the value of this index remained relatively favourable and proved that CR did not suffer substantially from excessive labour market regulations (Eurofound, 2007). World Bank (2009) shows that employment conditions in CR were better from entrepreneurs' viewpoint not only in comparison with the neighbouring countries, but even in comparison with countries like the Netherlands.
} 
the key message hidden behind the official methodology of assessing the readiness of the $\mathrm{CR}$ to enter the eurozone.

These two economic reasons, however disputable, served as an official justification of the Czech Republic's failure to enter the eurozone on January 1, 2009, and with a view to the current eurozone crisis thus closing the window of opportunity for an extended period. Nonetheless, our pre-crisis retrospective shows what should always be avoided in any serious decision making process linked with adoption of the euro:

Real or alleged difficulties in meeting the Maastricht Convergence Criteria and attaining economic alignment must serve as a mobilization factor for Czech economic policies. Instead, these issues were perceived to offer an objective reason against the adoption of the euro. The commitment to adopt the euro must be formulated and promoted in a much clearer manner by the coordinated forces of the government and the central bank.

From what we know today, it seems technically almost impossible that the CR will enter the eurozone earlier than in 2018-2020. In addition, before declaring the new euro changeover target date the government will probably want to see some empirical verification of the desired path of fiscal consolidation (hopefully without repeating profound fiscal forecasting errors or even manipulations). Possible risks linked with an inadequate economic alignment must be assessed on a realistic basis, too, i.e. without any deliberate overestimations. The same obviously applies to assessment of the future shape of the eurozone itself.

\section{References}

Analyses of the Czech Republic's Current Economic Alignment with the Euro Area (2008). Czech National Bank. Retrieved July 6, 2012 from http://www.cnb.cz/miranda2/export/sites/www.cnb.cz/en/monetary_policy/strategic_documents/download/ analyses of alignment 2008.pdf.

Assessment of the Fulfilment of Maastricht Convergence Criteria and the Degree of Economic Alignment of the Czech Republic with the Euro Area (2004-2008). Ministry of Finance of the Czech Republic and the Czech National Bank. Retrieved March 25, 2010, from http://www.zavedenieura.cz/cps/rde/xchg/euro/xsl/14.html.

BORGERSEN, T. A., KING, R. M. (2011). Reallocation and restructuring: A generalization of the Balassa-Samuelson effect. Structural Change and Economic Dynamics, Vol. 22, No. 4, pp. 287- 298. DOI: 10.1016/j.strueco.2011.07.001. ISSN: 0954-349X.

Convergence Programmes of the CR (2004-2008). Retrieved 16 June, 2011 from http://www.zavedenieura.cz/cps/rde/xchg/euro/xsl/dokumenty_vladni_material.html.

DĚDEK, O. (2002). Česká ekonomika a euro (Czech economy and the euro). Politická ekonomie, Vol. L, No. 3, pp. 361-375.

DYBCZAK, K., FLEK, V., HÁJKOVÁ, D., HURNÍK, J. (2006). Supply Side Performance and Structure in the Czech Republic. CNB Working Paper No. 4.

ECB (2008). Convergence Report. Frankfurt, European Central Bank. 
EGERT, B. (2002). Investigating the Balassa-Samuelson in the Transition: Do We Understand What We See? Economics of Transition, Vol. 10, No. 2, pp. 279-309. DOI: 10.1111/1468-0351.00112

Eurofound (2007). Fourth European Working Conditions Survey. Dublin, European Foundation for the Improvement of Living and Working Conditions.

European Commission (2008). Convergence Report 2008. European Economy 3/2008. Retrieved 16 June 2011, from http://ec.europa.eu/economy finance/publications/publication12574_en.pdf

European Commission (2010). Excessive deficits - Cyprus, Denmark and Finland join the watchlist. Press release, Retrieved 16 June, 2011, from http://ec.europa.eu/news/economy/100616_en.htm.

Fiscal Outlook of the Czech Republic (2009): Ministry of Finance of the Czech Republic. Retrieved 16 June, 2011 from http://www.mfcr.cz/cps/rde/xbcr/mfcr/FiskalniVyhled_2009Q1_komplet_doc.

FLEK, V. (2010). Euro jako naše budoucí měna: teorie a realita (Euro as our future currency: Theory and reality). In: Lacina, Rozmahel et al. (2010, pp. 261-265).

FLEK, V., ed. (2007): Anatomy of the Czech Labour Market: From Over-employment to Under-employment in Ten Years? Prague, The Karolinum Press.

FLEK, V., MARKOVÁ, L., PODPIERA, J. (2003). Sectoral Productivity and Real Exchange Rate Appreciation: Much Ado About Nothing? Czech Journal of Economics and Finance, Vol. 53, Nos. 3-4, pp. 130-153.

HÁJEK, M. (2008). Ekonomický růst v České republice a nových členských zemích Evropské unie (Economic growth in the Czech Republic and new EU member countries). Politická ekonomie, No. 4, pp. 435-448.

HELÍSEK, M. et al. (2009). Euro v ČR z pohledu ekonomu (Euro in the CR from the economists“ viewpoint). Plzeň, Aleš Čeněk Publishing.

Institutional Support for the Adoption of the Euro in the Czech Republic (2005).

Ministry of Finance of the Czech Republic. Retrieved 16 June, 2011 from http://www.zavedenieura.cz/cps/rde/xchg/euro/xsl/dokumenty_vladni_material.html.

KOMÁREK, L., ČECH, Z., HORVÁTH, R. (2003). Optimum Currency Area Indices How Close is the Czech Republic to the Eurozone? CNB Working Paper No. 10.

LACINA, L., ROZMAHEL, P. et al. (2010). Euro: ano/ne? (Euro yes/no?) Prague, Alfa.

LALINSKY, T. (2010). Zkušenosti Slovenska se zavedením eura (Slovakia's experience with Euro adoption). In: Lacina, Rozmahel et al. (2010, pp. 217-265).

LEIN, S. M., LEON-LEDESMA, M., NERLICH, C. (2008). How is real convergence driving nominal convergence in the new EU Member States? Journal of International Money and Finance, Vol. 27, No. 2, pp. 227-248. DOI: /10.1016/j.jimonfin.2007.12.004 
MIHAJLEK, D., KLAU, M. (2003). The Balassa-Samuelson Effect in Central Europe: A Disaggregated Analysis. BIS Working Paper No. 143.

MIHAJLEK, D., KLAU, M. (2008). Catching-up and inflation in transition economies: the Balassa-Samuelson effect revisited. BIS Working Paper No. 270.

MUNDELL, R. A. (1961). A Theory of Optimum Currency Areas. American Economic Review, Vol. LI, No. 4, pp. 509-517.

Ministry of Finance of the CR (2010): Macroeconomic prediction. Retrieved 16 June, 2011, from http://www.mfcr.cz/cps/rde/xchg/mfcr/xsl/makro_pre.html.

Protocol from the Czech National Bank Board Meeting held on 30 June 2005 (In Czech). Retrieved 6 July, 2012, from http://www.cnb.cz/miranda2/export/sites/www.cnb.cz/cs/menova_politika/br_zapisy_z_jednani/2005/2005_06_30/pt_06_SZ_30_06_0 $\underline{5 . p d f}$

STARK, J. (2008). The adoption of the euro: principles, procedures and criteria. Iceland Chamber of Commerce, Reykjavik, 13. February. Retrieved 16 June, 2011, from http://www.ecb.int/press/key/date/2008/html/sp080213.en.html

The Czech Republic's Euro-area Accession Strategy (2003). Retrieved 16 June, 2011, from http://www.zavedenieura.cz/cps/rde/xchg/euro/xsl/dokumenty_vladni_material. $\mathrm{html}$

The Czech Republic's Updated Euro-area Accession Strategy (2007). Retrieved 16 June, 2011 from http://www.zavedenieura.cz/cps/rde/xchg/euro/xsl/dokumentystrategie cr uerozony $382 . \mathrm{html}$

WORLD BANK (2009). Doing Business Report. Retrieved 16 June, 2011, from http://www.doingbusiness.org/EconomyRankings/. 